\title{
IPO pricing in the dot-com bubble
}

\author{
Alexander P. Ljungqvist \\ Stern School of Business \\ New York University \\ and $C E P R$
}

\author{
William J. Wilhelm, Jr. \\ Saïd Business School \\ Oxford University
}

First draft: November 12, 2001

This draft: February 8, 2002

\footnotetext{
${ }^{*}$ We are grateful to Yakov Amihud, Edie Hotchkiss, Michelle Lowry, N.R. Prabhala, Jay Ritter, an anonymous referee, and especially Rick Green, for helpful comments. The paper has benefited from seminar presentations at the University of Florida and Oxford University. All errors are our own.

${ }^{\dagger}$ Address for correspondence: Stern School of Business, New York University, Suite 9-190, 44 West Fourth Street, New York NY 10012-1126. Phone 212-998-0304. Fax 212-995-4233. e-mail aljungqv@ stern.nyu.edu.
} 


\title{
IPO pricing in the dot-com bubble
}

\begin{abstract}
IPO initial returns reached astronomical levels during 1999-2000. We show that the regime shift in initial returns and other elements of pricing behavior can be at least partially accounted for by a variety of marked changes in pre-IPO ownership structure and insider selling behavior over the period which reduced key decision-makers' incentives to control underpricing. After controlling for these changes, there appears to be little special about the 1999-2000 period, aside from the preponderance of internet and high-tech firms going public. Our results suggest that it was firm characteristics that were unique during the "dot-com bubble" and that pricing behavior followed from incentives created by these characteristics.
\end{abstract}

Key words: Initial public offerings; Underpricing; Intermediation; Internet; Hot issue markets. JEL classification: G32, G24 


\section{Introduction}

In 1996, first-day returns on IPOs averaged about 17\% (median: 10\%). In 1999, first-day returns averaged 69\% (median: $35 \%$ ) before tapering off to $56 \%$ (median: $29 \%$ ) in 2000 . Internet IPOs averaged a stunning 88\% (median: 56\%) during 1999 and 2000. These average returns dwarf those from earlier periods and are the most widely recognized feature of what is now commonly referred to as the "dot-com bubble".

Existing explanations for the initial return behavior of IPOs focus in large part on informational frictions that arise among the various parties to the transaction. ${ }_{\text {Although it is }}$ conceivable that informational frictions became more severe during the dot-com bubble, it strains belief that even collectively this body of theory can account for the profound change in market behavior. With this in mind, Loughran and Ritter (2001b) conjecture that issuers grew complacent as valuations spiraled, thereby heightening the agency conflict between issuers and their banks [Baron (1982), Biais et al. (2000)]. In this paper we document profound changes in the incentive structure surrounding the IPOs of 1999 and 2000 that go well beyond spiraling valuations.

For example, in 1996 pre-IPO insider ownership stakes averaged 63\% but by 2000 had declined to $51 \%$. CEO stakes declined even more dramatically, halving from $22.8 \%$ to $11.5 \%$. Similarly, equity stakes held by VCs and investment banks, as well as those held by other corporations, declined sharply in magnitude over the period. As a consequence, ownership became increasingly fragmented. Alongside these changes in ownership structure, 1999-2000 witnessed a sharp decline in both the frequency and magnitude of secondary sales of existing shares by all categories of pre-IPO owners, and especially CEOs. Finally, directed share programs - which

\footnotetext{
${ }^{1}$ Among these are explanations based on the 'winner's curse' [Rock (1986)], signaling [Allen and Faulhaber (1989), Welch (1989)], cascades [Welch (1992)], and investor incentives to reveal information truthfully [Benveniste and Spindt (1989)].
} 
provide family, friends, employees, suppliers, and occasionally VCs the opportunity to purchase shares at the IPO price - appeared in only $25 \%$ of IPOs marketed in 1996, but $76 \%$ in 1999 and $91 \%$ in 2000 .

Standard principal-agent theories predict that agents will expend less effort in bargaining and monitoring on behalf of their principals when the agents' stake in the transaction is smaller. From this perspective, these changes in ownership structure and selling behavior should undermine the incentives of those most directly involved in bargaining over the offer price. We test this hypothesis from the mechanism design perspective suggested by Benveniste and Spindt (1989) and generalized by Biais et al. (2000) to incorporate the conflict of interest between issuers and their underwriters studied by Baron (1982). This theoretical framework provides structure for modeling both price revisions between the IPO registration and offer dates and initial returns. From this perspective, underpricing is significantly lower when insider ownership stakes are larger and less fragmented and when insiders sell more shares at the offer price. Our empirical results provide strong support for these predictions, and so suggest an association between the aberrant pricing of the dot-com bubble and changes in ownership structure and insider selling behavior.

Controlling for insider ownership and sales increases substantially the explanatory power of our regressions and accounts for a good deal of what apparently set issuers during the dot-com bubble apart from their predecessors. For example, in the underpricing regressions, dummy variable coefficients associated with high-tech and internet firms decline by more than 60\% (but remain statistically significant) from estimates obtained without controlling for changes in ownership structure and secondary selling behavior. Similarly, the dummy variable coefficient for the "bubble" years 1999 and 2000 declines by more than a half. 
These findings are robust to a variety of alternative specifications. Among other things, we have allowed for several sources of potential endogeneity bias and considered whether there is sufficient information to separately identify firm-specific effects and those associated with the bubble dummy variable. Our central conclusion does not change. In sum, both price revisions and underpricing during the dot-com bubble, although profoundly aberrant from a historical perspective, can be at least partially explained by equally profound changes in pre-IPO ownership structure and insider selling behavior.

\section{Sample and data}

The sample consists of firms completing an initial public offering between January 1996 and December 2000. Most IPO prospectuses since early May 1996 are available on the S.E.C. Electronic Data Gathering, Analysis, and Retrieval (EDGAR) service. Prospectuses for issues in January-April 1996 and for foreign issuers (who do not have to file electronically with EDGAR) are obtained directly from the firms, from Disclosure's Global Access, and in the case of Canadian issuers, from the System for Electronic Document Analysis and Retrieval (SEDAR). Thomson Financial's SDC database lists 2,399 completed IPOs during 1996-2000, after excluding unit offers, closed-end funds (including REITs), ADRs of companies already listed in their home countries, and limited partnerships. In total, we have prospectuses for all but two of the 2,399 sample IPOs. Ideally, the sample would extend further back in time. Given the difficulty of compiling prospectus data prior to 1996 , we provide one historical reference point by obtaining prospectuses for the 185 firms that, according to SDC, completed a bona fide IPO during the

\footnotetext{
${ }^{2}$ For further information regarding the sample construction, see Benveniste, Ljungqvist, Wilhelm, and Yu (2001).

${ }^{3}$ Unlike Loughran and Ritter (2001a, 2001b) we do not exclude IPOs with low offer prices. Dropping the 5.5\% of sample firms with offer prices below $\$ 5$ does not alter our results.
} 
fourth quarter of 1993. We refer to this set of firms as the $93 Q 4$ reference sample. Finally, we summarize withdrawal patterns over the period by assembling an SDC-generated sample of 795 firms that withdrew their offerings in 1996-2000.

SDC contains little information on ownership structure, so we hand-collect data on CEO, VC, corporate, and investment bank ownership from prospectuses. We classify stakes held by a VC fund affiliated with an investment bank as an investment bank-held stake. We use Pratt's Guide to Venture Capital Sources, the Venture Economics database, and VCs' web sites to identify investment bank-affiliated VC organizations. In addition, investment bank ownership also includes stakes held by the bank directly. We also identify whether the relevant bank is a member of the underwriter syndicate. Data on the incidence and size of directed share programs also is collected from the issuer's prospectus.

There are significant errors in SDC's variables for venture-backing, syndicate size, shares outstanding pre- and post-IPO, aggregate insider equity holdings pre- and post-IPO, earnings per share before the IPO, and use of proceeds, so we hand-collect these variables as well. ${ }_{\text {We }}$ use some SDC accounting data (the book values of assets and equity, revenue, and net income) purely for illustrative purposes. These have only been checked for outliers.

Internet companies are identified as in Loughran and Ritter (2001b), with slight modifications. For the withdrawn offerings, internet companies are identified on the basis of SDC's business descriptions. We hand-fill gaps in SDC's coverage of company founding dates and manually check all firms that according to SDC were 0-3 years old at the IPO, since Loughran and Ritter (2001b) note that SDC frequently reports the most recent incorporation date rather than the founding date. As in Loughran and Ritter (2001b), the founding date is defined as the date when

\footnotetext{
${ }^{4}$ A detailed discussion of the errors we found in the SDC data can be found at http://pages.stern.nyu.edu/ aljungqv/research.htm.
} 
operations commenced. In IPOs of corporate divisions, we attempted to determine the date when the division commenced operations. This date normally preceded the date of the division's incorporation. In roll-ups and similar acquisition-based IPOs, the founding date of the IPO company is the earliest founding date of any of its constituent firms.

First-day trading prices are generally from CRSP. 211 sample firms are not covered in CRSP, so we use the prices reported in SDC and verify them against news sources and the share price database on bigcharts.com. After-market prices were not available for three sample firms.

\section{How issuing firms changed between 1996 and 2000}

\subsection{Firm characteristics}

Table 1 provides a snapshot of the annual variation in issuing firm characteristics between 1996 and 2000. We test the significance of changes over time by regressing each characteristic on an annual time trend $t$, and report, in the last column of the Table, the significance level of the coefficient estimated for $t$. We use OLS to test for trends in means, median regressions to test for trends in medians, and probit regressions to test for trends in binary variables. Unless noted explicitly, every characteristic has a significant time trend.

Across the entire period, internet firms accounted for $20 \%$ of the sample but there was substantial variation within the period. In 1999, 55\% of IPOs were carried out by internet firms, compared to $3-12 \%$ in the earlier years and $36 \%$ in 2000 . High-tech companies (using the classification in Loughran and Ritter (2001b)) accounted for a third or less of the sample in 1996-8 but close to a half in 1999-2000. 
Age at issue declined over the period. The average issuer was 14-18 years old in 1996-8 vs. 10-11 years in 1999-2000. The median fell by about a third, from 8-9 years in 1996-8 to 5-6 years in 1999-2000. This is consistent with the patterns documented in Loughran and Ritter (2001b).

Revenue figures are heavily right-skewed, reflecting the presence of some well-established businesses such as Lucent Technologies (1996), Hartford Life (1997), Fox Entertainment Group (1998), United Parcel Service (1999), and MetLife (2000). It is therefore more meaningful to focus on median revenues, which fell sharply over the period, from \$22.8 million in 1996 to \$10.6 million in 2000. The book values of assets and equity are right-skewed for similar reasons, so we again focus on medians. Median assets increased over the period, from $\$ 17.6$ million to $\$ 34.3$ million, while median equity (before the cash infusion from the IPO) fell and even turned negative in 2000. This implies that median liabilities (assets - equity) increased over the period.

Profitability, as measured by net income after taxes in the most recent 12 -month period before the IPO, shows a clear declining trend. The median company in 1996-8 was modestly profitable, with net income between $\$ 300,000$ and \$1 million, whereas in 1999-2000 the median company lost between $\$ 4.9$ million and $\$ 8.5$ million. The fraction of issuing firms with negative or zero earnings rose from $43 \%$ of sample firms in 1996 to more than $75 \%$ in $1999-2000$.

\subsection{Transaction characteristics}

Table 2 reports characteristics of IPO transactions. Mean gross proceeds nearly trebled over the period ( $\$ 58.8$ million in 1996 vs. $\$ 170.4$ million in 2000 ). Medians remained relatively stable in 1996-8, around $\$ 32-36$ million, but then jumped to $\$ 60$ million in 1999 and $\$ 76.8$ million in 2000. The use of proceeds also changed sharply. The incidence of firms raising money primarily to fund operating expenses (such as sales and marketing, working capital), as opposed to debt reduction, funding acquisitions, or capital expenditure, rose from 39\% of IPOs or less in 1996-8 to 
$66 \%$ in 1999 and $72 \%$ in 2000 . Thus firms increasingly turned to the IPO market to finance dayto-day operations, rather than investment plans or balance sheet restructuring. In large part, this pattern reflects the decline, or even absence, of current earnings in 1999-2000.

The average underwriting syndicate consisted of more than 18 banks in 1996, falling to around 15 in 2000. This is noteworthy given the increase in offer size over the period. On risk sharing grounds, one might expect an increase in syndicate size. Though not shown in Table 2, the number of lead and co-lead underwriters (SDC variable NUMMGR) actually increased, from 2.3 in 1996 to 3.6 in 2000 , implying an even sharper decline in the number of non-managing syndicate members over the period. Using the Loughran and Ritter (2001b) updated version of the CarterManaster (1990) underwriter reputation ranking (scaled from 0 to 9.1), the mean underwriter ranking increased from 6.9 in 1996 to 8.3 in 2000. Indeed, from 1999 onwards, the median IPO firm hired a top-ranked (rank of 9.1) investment bank.

The expected offer price, reflected in the mean of the indicative price range included in the issuer's S-1 filing, increased from \$11.94 in 1996 to \$13.36 per share in 2000 (the median increased one dollar to $\$ 13$, but this trend is not significant). The withdrawal frequency [number of withdrawals in year $t$ / (number of withdrawals + completed IPOs in year $t$ )] among sample firms in 1996 was about $10 \%$. This frequency rose sharply over the sample period culminating in a withdrawal frequency of $38 \%$ in 2000. In 2000 , internet companies accounted for $66 \%$ of the 230 withdrawn offerings. Conditional on completing the offering, final offer prices also increased over the period, from a mean of $\$ 12$ in 1996 to $\$ 14.78$ in 2000 (the median rose from $\$ 12$ to $\$ 14$ ). The 2000 mean offer-price level exceeded any during the 16-year period beginning in 1985 .

Concurrently, the average price revision from the mean of the indicative price range rose from

\footnotetext{
${ }^{5}$ Withdrawals also spiked in 1998 as firms abandoned their IPOs in the wake of the LTCM failure (in September and October 1998, withdrawn IPOs outnumbered completed ones by nine to one).
} 
zero in 1996 (with $23 \%$ of sample firms priced above the upper end of the filing range and $23 \%$ priced below the lower end) to a high of $17 \%$ in 1999 (when $47 \%$ of offerings were priced above the suggested price range and only $15 \%$ below). The price revision distribution remained highly skewed in 2000. Despite the rising frequency of positive revisions, average first-day returns increased sharply and their distribution became considerably more right-skewed, with extreme positive outliers increasing in both frequency and size.

A final distinguishing feature of the 1996-2000 transactions is the growing popularity of directed share programs (DSPs), sometimes referred to as friends and family programs. In a DSP, the issuer sets aside a fraction of the IPO for preferential allocation to designated individuals (including executives and other board members) or members of pre-defined groups such as employees, customers, strategic corporate partners etc. In 1996, 25\% of IPOs included a DSP, compared to $19 \%$ in the $93 \mathrm{Q} 4$ reference sample. The fraction rose to $76 \%$ of issuers in 1999 and $91 \%$ in 2000 . The average size of the DSP remained stable in the $1996-2000$ period, averaging around $7 \%$ of the shares on offer, with clustering at 5\% and 10\%. In the 93Q4 reference sample, the average DSP is somewhat smaller, at $5.4 \%$, and clustering is less pronounced.

\subsection{Changes in the pre-IPO ownership structure of issuing firms}

The S.E.C. requires issuers to disclose, in their prospectus, the beneficial ownership of common stock by directors, director nominees, and executive officers as well as each person or entity with an equity stake exceeding $5 \%$ of the outstanding stock. ${ }^{\square}$ Frequently, issuers voluntarily disclose smaller stakes as well. The prospectus also reports the aggregate stake held by all

\footnotetext{
${ }^{6}$ Unfortunately, prospectuses often fail to identify specific beneficiaries, and virtually never provide a share breakdown, so it is impossible to systematically collect quantitative or qualitative information on allocations to key decision-makers such as the CEO.

${ }^{7}$ Beneficial ownership includes options that are exercisable within 60 days of the IPO. In the case of firms with dual class stock, we compute ownership as the fraction of cash flow rights (as opposed to control rights) an individual holds.
} 
directors and executive officers as a group, whom we refer to collectively as insiders. This measure excludes stakes held by anyone who is not represented on the board and is not a senior executive of the firm (e.g., employee stock ownership programs, junior participants in syndicated VC funding rounds, or corporate investors holding only small stakes). By this measure, pre-IPO insider ownership averages $60 \%$ over the sample period. Table 3 shows a monotonic decline in average insider ownership from $63 \%$ in 1996 to $51 \%$ in 2000.

Over the entire sample period, CEOs on average owned $20.6 \%$ of pre-IPO shares outstanding. This is comparable to levels documented by Baker and Gompers (1999). The distribution of CEO stakes is right-skewed, reflecting the presence of closely held firms managed by their founders; median CEO ownership is $8.9 \%$. CEO ownership declined from $22.8 \%$ in 1996 to $11.5 \%$ in 2000 on average, or from $10.7 \%$ to $5.2 \%$ for the median firm - despite firms being younger. By comparison, in the 93Q4 reference sample the average (median) CEO owned 24\% (10.8\%).

Investment banks held equity stakes in a quarter of companies over the sample period. These stakes can be direct holdings (perhaps reflecting payment for services rendered) or indirect holdings by a bank's private equity or venture capital funds. In the first three years of the sample period, bank-held stakes were present in only 14\% to $21 \%$ of sample firms. In 1999 and 2000, by contrast, this fraction rose to $39.8 \%$ and $43.6 \%$, respectively. Conditional on having a bank-held stake, the mean stake size ranged from $14 \%$ to $24 \%$ with a sample mean of $16.7 \%$. The data reveal a modest negative trend in the mean stake size over the period that is significant at the $1 \%$ level.

When an investment bank is a shareholder, it usually, but not always, acts as an underwriter. The frequency with which this occurred peaked at more than 79\% in 1999 and 2000. NASD Conduct Rule 2720 requires the appointment of a 'qualified independent underwriter' (QUI) in cases where one of the lead underwriters is a beneficial owner of $10 \%$ or more of any of an 
issuer's class of outstanding securities or is participating in the distribution of an affiliate's shares. (The definition of an affiliate includes, for instance, parent companies.) The QUI's role is to perform due diligence on the company, review and participate in the preparation of the prospectus and registration statement, and recommend a maximum price for the offering to mitigate fears of overpricing.

Across the entire sample, 1,220 of the 2,399 IPOs were backed by (non-investment bank affiliated) venture capital or private equity funds. We refer to these collectively as VC-backed IPOs. In 1996-1998, VC-backed companies accounted for only 37\% to $47 \%$ of IPOs. By contrast, 62\% of issuing firms were VC-backed in 1999 and 71\% in 2000. Aggregate venture capital stakes, hand-collected from IPO prospectuses, declined over the period, from $43.9 \%$ of pre-IPO equity in 1996 to $37.7 \%$ in 1999 , before rising again in 2000 , to $40.4 \%$.

Corporations held equity stakes in 899 sample firms (37.5\%). owned subsidiaries spun off by their parents, and cases where corporations such as Cisco and Microsoft, or Pfizer and Merck, held strategic stakes in firms in their respective industries. Conditional on corporate stakes being present, the average stake size fell by around a quarter over the period, from $44 \%$ in 1996 to $33 \%$ in 2000.

Computing a Herfindahl index as the sum of the squared ownership interests of the CEO, VC, corporate, and investment banking shareholders provides a summary measure of ownership concentration. The index ranges from zero to one, with zero corresponding to the number of shareholders tending to infinity and one indicating a single shareholder. By construction, the index rises with variation in ownership stakes. Thus, a company with two shareholders holding $90 \%$ and $10 \%$, respectively, is more concentrated than a company with two shareholders holding $50 \%$ each.

\footnotetext{
${ }^{8}$ We do not count as corporate stakes equity held by 'shell' companies owned by founders or executives.
} 
In the sample as a whole, the index measures 0.347 and trends down over time, from 0.365 in 1996 to 0.321 in 2000 , suggesting that pre-IPO ownership fragmented over time.

\subsection{Changes in insider selling behavior and post-IPO ownership structure}

Table 4 summarizes a sharp decline in the frequency of insider sales over the sample period. About one third of IPOs included secondary stock in 1996-1998. In 1999, 19.5\% of IPOs included secondary sales and the fraction declined further to $9.1 \%$ in 2000 . As a consequence, the average fraction of pre-IPO shares outstanding sold at the IPO declined, from $4.7 \%$ in 1996 to $0.9 \%$ in 2000, as did the share of secondary sales in the average offer, from $9.8 \%$ in 1996 to $2.5 \%$ in 2000 .

The frequency of secondary sales by CEOs declined even more sharply, to only $1.1 \%$ of sample firms in 2000. In 1996, VCs participated in secondary sales in $23 \%$ of the IPOs by firms they backed. The frequency declined to $6.3 \%$ in 1999 and 2.6\% in 2000. Likewise, in 1996 secondary sales by investment banks occurred in $23 \%$ of the IPOs in which banks held equity stakes and rose to $34 \%$ in 1997 before returning to $24 \%$ in 1998 . In 1999 , the frequency of such sales fell to $7.7 \%$ and then to $2.5 \%$ in 2000 . The incidence of sales by corporate shareholders fell from $28 \%$ in 1996 to $8 \%$ in 2000. Post-IPO insider ownership declined much less sharply (and indeed not significantly), from $43.4 \%$ in 1996 to $40.5 \%$ in 2000 , reflecting both the reduction in the incidence and amount of insider selling, and smaller offer sizes as a fraction of shares outstanding (the free float).

\section{The determinants of price revisions and underpricing}

In this section we examine the influence of changes in pre-IPO ownership structure and insider selling behavior on the price revision process and initial returns during the dot-com bubble. We use ordinary least squares to provide a benchmark estimation of each model. We later allow for possible reverse causality and potential endogeneity of several key explanatory variables. 


\subsection{Price revisions}

Price revisions are measured as the percentage difference between the offer price and the mean of the indicative price range. Price revisions are assumed to reflect information acquired from informed investors. Benveniste and Spindt (1989) argue that truthful revelation of positive information requires favoring cooperative investors with preferential allocations of underpriced shares. Thus, underwriters only 'partially adjust' the offer price to the information they acquire. Other things equal, revelation of more favorable information requires a greater inducement implying a positive relation between price revisions and initial returns of the sort first observed by

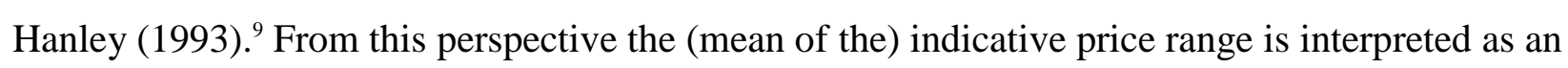
unconditional expectation of the issuer's share value, with the offer price then a conditional estimate.

Other things equal, insiders should bargain for more aggressive positive revisions when their stakes are larger and more concentrated and when they are selling more secondary shares in the IPO. Thus we predict a positive relation between price revisions and the various measures of insider ownership stakes and concentration and a positive relation between price revisions and measures of insider sales. We attempt to isolate these effects by controlling for firm and offer characteristics.

We also control for valuation-relevant information that comes to light during a company's bookbuilding phase. Specifically, we conjecture that relevant information may "spill over" from the secondary market and from the bookbuilding experiences of contemporaneous offerings. We attempt to capture the former by including the return on a share price index, measured from the

\footnotetext{
${ }^{9}$ The positive relation is reinforced by efficiency considerations that call for concentrating shares discounts in states where there is little risk of allocating discounted shares to investors who showed weak interest in the deal. See Benveniste and Spindt (1989) and Benveniste and Wilhelm (1990) for development of this point.
} 
filing date to the effective date of the offering. We use an industry-specific index to isolate information spilling over from firms sharing a common valuation factor with the issuing firm. The industry index is computed as the equally-weighted return on firms in a particular Fama-French (1997) industry, using the universe of firms available in CRSP.

Benveniste, Busaba, and Wilhelm (2002) argue that price revisions incorporate information spilling over from the bookbuilding efforts of the issuer's contemporaries in the primary market. For instance, if other firms subject to a common valuation factor have revised their prices up aggressively, an issuing firm may infer that investors have revealed positive information about the valuation factor and increase its offer price in response. We define an issuer's contemporaries as firms in the same Fama-French industry completing an IPO between the issuer's registration and offering dates. Following the Benveniste-Spindt (1989) intuition, we use the mean initial return of the issuer's contemporaries as the measure of the information revealed in contemporaries' IPOs.

Table 5 reports the least-squares estimation of four models that differ in the ownership and insider sale variables we include but otherwise control for the same effects. Standard errors are adjusted for the bias caused by time clustering of observations. 2 Some care should be taken in interpreting the coefficients because extreme negative feedback increases the likelihood of an offer being withdrawn. For instance, Benveniste, Ljungqvist, Wilhelm, and Yu (2001) show that firms in 'nascent' industries are more likely to withdraw in response to negative news and increase their

\footnotetext{
${ }^{10}$ Fama and French aggregate firms by 4-digit SIC code into 48 industries. Benveniste, Ljungqvist, Wilhelm, and Yu (2001) show that spillovers based on this aggregation are more informative than spillovers defined by individual SIC codes.

${ }^{11}$ We follow Benveniste, Ljungqvist, Wilhelm, and Yu (2001) in our specification but see also Lowry and Schwert (2001) on this point.

${ }^{12}$ When many companies go public at the same point in time, it is questionable whether their residuals are crosssectionally independent. Thus, we replace the i.i.d. assumption with the weaker assumption that observations are independent for companies at different points in time, but not necessarily for companies going public in the same month, and adjust the variance estimator accordingly.
} 
proceeds in response to positive news. Thus, the coefficients we report are estimated conditional upon an offering going ahead.

Note first that pre-IPO ownership stakes appear to have little influence on price revisions. This is true in both model [1] where we control separately for the stakes of CEOs, venture capitalists, investment banks and corporate shareholders and in model [2] where we control for the level of ownership concentration. Model [3] introduces insider sales, measured as the reduction in shares owned by directors and executives as a group, relative to shares outstanding. This variable has the predicted positive effect on price revisions but is insignificant. In model [4] we disaggregate insider sales into sales by CEOs, VCs, other corporations, and investment banks and find that the sales of the first two are associated with larger price revisions ( $p=5.9 \%$ and $p=7 \%$, respectively). Specifically, a $1 \%$ increase in the size of CEO or VC sales increases offer prices by a little under $0.3 \%$ and $0.15 \%$, respectively, relative to the midpoint of the range.

The coefficients estimated for contemporaneous underpricing and the industry return are highly significant $(p<0.1 \%)$ and suggest a large economic influence over price revisions. A twoquartile increase in mean underpricing among contemporaneous offerings, from the first to the third quartile, translates into an increase in the issuer's price revision from $1.5 \%$ to $6.9 \%$, holding all other covariates in model [4] at their sample means. In other words, we observe substantially more aggressive pricing when the issuer's contemporaries are enthusiastically received by investors and therefore suffer more severe underpricing. Similarly, a corresponding increase in the industry return translates into an increase in the issuer's price revision from $2.1 \%$ to $6.4 \%$. Although not reported in Table 5, a market-wide index (the equally-weighted combined CRSP index) has no additional explanatory power in the models estimated. 
Price revisions are inversely related to the log of the issuing firm's age ( $p<5 \%$ across the four models) and larger for high-tech $(p<4 \%)$ or internet-related firms $(p<0.1 \%)$. Our interpretation of these variables is that younger firms and 'new economy' firms suffer greater uncertainty. From the Benveniste and Spindt perspective, such firms are most likely to benefit from information acquisition during bookbuilding. The signs estimated for each coefficient are consistent with this interpretation, bearing in mind that extreme negative feedback received during bookbuilding would likely lead such firms to withdraw instead. Continuing this line of reasoning, price revisions increase with bank reputation $(p<0.1 \%)$ suggesting that more reputable banks extract more information from potential investors and incorporate it more aggressively in the offer price.

Syndicate size has a negative effect on price revisions $(p<2 \%)$. Aggarwal, Prabhala, and Puri (2001) use proprietary allocation data to show that larger syndicates allocate significantly more stock to retail investors. Higher retail allocations, in turn, may come at the expense of less price discovery in the bookbuilding phase [Ljungqvist and Wilhelm (2001)]. The negative sign on the coefficient estimated for syndicate size is consistent with this interpretation. Alternatively, syndicate size may simply pick up larger offerings tending to have smaller revisions [Benveniste, Ljungqvist, Wilhelm, and Yu (2001)]. However, if we control separately for the log of the filing amount (not shown), we continue to find a significant and negative relation between syndicate size and price revisions.

In Table 2, we showed that price revisions were substantially larger in 1999 and 2000. In the regressions of Table 5, the statistical insignificance of the (bubble) dummy variable for the years 1999 and 2000 indicates that changes in firm and offer characteristics and in insider selling behavior can fully explain the time series patterns in price revisions in Table 2. In other words, we 
find no evidence that price revisions during the dot-com bubble behaved differently after controlling for other factors.

Self-selection bias may cause the coefficients estimated for the effect of bank reputation on the extent of price revisions in models [1]-[4] to overstate the beneficial effect of engaging a highly ranked bank. If firms with the most to learn during bookbuilding choose the top underwriters, the positive correlation between bank reputation and price revisions may not be causal but a byproduct of the selection behavior of such firms. We therefore estimate a 2SLS version of model [4] that explicitly treats underwriter choice as endogenous [see also Habib and Ljungqvist (2001)]. The first stage relates underwriter choice to all independent regressors in [4] and two additional variables added to ensure identification: a dummy equaling one if the issue is VC-backed, and the $\log$ of the intended offer size, in $\$$ million. ${ }^{13}$ The coefficient estimates are reported as model [5].

In short, more prestigious underwriters are chosen by venture-backed or older firms, those filing larger offers, and companies with greater valuation uncertainty (as captured by the two dummies for high-tech and internet businesses). Historically, as Loughran and Ritter (2001b) point out, prestigious investment banks did not underwrite offerings by high-risk issuers. However, such issuers have more to gain from the (presumably) superior information production or certification capability of a prestigious bank, and so it makes sense that we find a positive relation between underwriter rank and valuation uncertainty in our sample period.

Higher-quality underwriters may enable insiders, such as the CEO, to sell more equity in the IPO, perhaps because their certification ability allows the insiders to sell more shares without

\footnotetext{
${ }^{13}$ Davidson and MacKinnon (1993, p. 236) outline a test of the joint null hypothesis that the equation is properly specified and the instruments are valid instruments (i.e. uncorrelated with the error term of the $2^{\text {nd }}$ stage regression). The test is based on a regression of the IV residuals on the full instrument matrix and generates a Lagrange Multiplier statistic which under the null is distributed $\chi^{2}(\mathrm{~m})$, where $\mathrm{m}$ is the number of over-identifying restrictions $(1$, in our case). In our 2SLS model, the test statistic is $0.067(p=0.796)$. We can thus not reject that VC backing and the log of intended offer size are valid instruments.
} 
negative repercussions. If an underwriter's certification ability is well-known, then it seems reasonable that insiders who intend to sell more equity will take certification ability into account when making their choice of underwriter. We therefore treat insider sales as exogenous in the underwriter choice model. We find that CEO sales are positively associated with higher-ranked underwriters $(p=1.4 \%)$, consistent with the hypothesis that CEOs take a greater interest in the quality of their lead manager when they sell stock in the IPO. VC sales, on the other hand, have a negative association with underwriter reputation $(p=0.3 \%)$. This is consistent with anecdotal evidence that top underwriters frequently dissuade VCs from selling at the IPO.

The coefficient estimated for the bubble dummy is not significant $(p=34.5 \%)$. This contrasts with the univariate results in Table 2 indicating a trend towards more prestigious underwriters over the period. The multivariate results in Table 5 suggest that the main cause of this trend is an increase over time in the type of issuer that benefits from choosing a more prestigious underwriter.

Using the predicted investment bank rankings from [5] as instruments, model [6] provides consistent estimates of the effect of underwriter reputation on price revisions. Comparing columns [4] and [6] indicates that controlling for selection has the predicted effect of reducing the bank reputation coefficient (by a third). However, the bank coefficient remains highly significant $(p=1.7 \%)$ and positive, so higher-ranked banks are still associated with greater price revisions, after controlling for the endogeneity of bank choice. This finding does not support the notion that top-ranked underwriters deliberately exploited naïve or complacent issuers unless greater price revisions reflect low-balling in the setting of the price range rather than price discovery. ${ }^{4}$ Note

\footnotetext{
${ }^{14}$ Loughran and Ritter (2001b) interpret the sharp increase in price revisions documented in Table 2 as evidence of investment bankers low-balling the indicative price range as the first stage of exploiting the complacency of issuers. Low-balling implies that subsequent price revisions are predictable on the basis of information that was known when the price range was set. Testing this proposition is made more difficult by the asymmetry introduced when companies withdraw their IPOs in response to negative feedback received during bookbuilding, as discussed earlier.
} 
also the improved significance $(p<5 \%)$ of the CEO and VC sales coefficients in the price revisions model when underwriter choice is treated as endogenous.

\subsection{Underpricing}

As a starting point for the underpricing analysis, we estimate a simple regression of initial returns on dummy variables for high-tech and internet firms and the bubble years 1999-2000:

$$
\begin{array}{r}
\text { Initial return }=0.094+0.174 \text { hightech }+0.379 \text { Internet }+0.280 \text { bubble } \\
0.014 \quad 0.030
\end{array}
$$

Time cluster-adjusted standard errors are shown in italics beneath the coefficient estimates. The $R^{2}$ of the regression is $20.9 \%$. If the increase in underpricing levels in the dot-com bubble was driven by changes in issuer incentives, then the coefficient on the bubble dummy should tend toward zero after controlling for issuer incentives.

Table 6 reports the least-squares estimates of four models, mirroring those in Table 5, that again differ in the ownership and insider sale variables while controlling for a fixed set of firm and offer characteristics. In addition to the variables included in the price revision regressions, we introduce several additional firm and offer characteristics based on the univariate results reported in Tables 1-4. Habib and Ljungqvist (2001) model the effect of participation and dilution on underpricing and show both theoretically and empirically that initial returns are lower, the more pre-IPO shareholders sell or the greater the increase in shares outstanding as a result of the issuance of primary stock. We therefore control for the participation ratio (the number of secondary shares sold relative to pre-IPO shares outstanding) and the dilution factor (the number of primary shares sold relative to pre-IPO shares outstanding). We also conjecture that a directed share program creates an incentive to underprice an offering in order to benefit the targeted clienteles and thus control for the size and presence of DSPs. 
In addition to using log age, we include the intended use of proceeds as a proxy for valuation uncertainty. When issuers plan to use the proceeds to finance operating expenses or working capital, we conjecture that there is greater uncertainty about the financial sustainability of their business model. To capture the partial adjustment phenomenon first documented by Hanley (1993), we include the price revision relative to the midpoint of the filing range, and to allow for possible asymmetries in pricing [Lowry and Schwert (2001)], we include a variable which equals the price revision if it is positive, and zero otherwise.

Once again, the coefficient estimates are stable across all models, reported in columns [7]-[11], and the explanatory power of the regressions is high $\left(R^{2}\right.$ in excess of $\left.45 \%\right)$. Among firm characteristics, underpricing is inversely related to the log of the issuing firm's age $(p<5 \%)$. Consistent with the findings of Habib and Ljungqvist (2001), underpricing is inversely related to the participation ratio and the dilution factor ( $p<5 \%$ in most instances). In other words, underpricing is more severe when current shareholders have less at stake in the level of the offer price. Underpricing increases by about $0.6 \%$ for every $1 \%$ increase in the fraction of the offering set aside for directed share programs $(p<5 \%)$. As conjectured, offerings aimed at funding operating expenses are more severely underpriced, by about 7 percentage points $(p<5 \%)$.

In contrast to the strong effect of investment bank ranking on price revisions, bank reputation does not influence the degree of underpricing, after controlling for other effects. Thus, underwriter quality appears to influence initial returns only indirectly by influencing price revisions. The indirect effect is consistent with the Benveniste-Spindt (1989) framework, for more active and prestigious banks should have more leverage to extract information from investors, leading to more aggressive proceeds revisions. A direct effect would be more nearly consistent with the Carter-Manaster (1990) and Booth-Smith (1986) framework where prestigious underwriters 
transfer 'certification' benefits rather than offer superior information production. It is possible, however, that the apparent lack of a relation between bank reputation and underpricing is due to the modeling assumption that underwriter choice is exogenous [see Habib and Ljungqvist (2001) for similar reasoning in the 1991-1995 period]. We investigate this possibility in Section 5.

Underpricing is directly related to the magnitude of price revisions $(p<1 \%)$, and the statistical significance of price revision ${ }^{+}(p<1 \%)$ is consistent with asymmetric partial adjustment of the sort envisioned by Benveniste and Spindt (1989) and documented by Hanley (1993) and Lowry and Schwert (2001). In Table 2 we documented a rising frequency of positive revisions in 1999 and 2000 , so price revision ${ }^{+}$may merely pick up a change in the slope of the relation between price revisions and underpricing over the sample period. Replacing price revision ${ }^{+}$with an interaction term, price revision ${ }^{\text {bubble }}$, that equals price revision in 1999-2000 and zero otherwise, produces similar coefficients. Since the results reported in Table 5 indicate that price revisions behaved no differently in 1999-2000 than in 1996-8 after controlling for insider sales and firm characteristics, the interaction term must be interpreted with caution. We return to this problem in Section 5, where we estimate a two-stage model of underpricing.

Controlling for firm and transaction characteristics, the pre-IPO ownership stakes of the CEO, other corporations, venture capitalists, and investment banks (model [7]) all have a negative effect on underpricing, significantly and strongly so for corporate $(p=0.4 \%)$, $\mathrm{VC}(p=0.5 \%)$, and investment bank ( $p=0.7 \%)$ stakes. The lack of significance for the CEO ownership coefficient is unexpected given the results for the other ownership variables. Column [8] reports the results of estimating a modified version of [7], in which we interact CEO ownership stakes with the dummy identifying internet companies. This interaction term has a negative and highly significant coefficient $(p=0.4 \%)$ suggesting that CEOs of internet companies behave much like corporate, 
$\mathrm{VC}$, or investment bank owners in taking a greater interest in reducing underpricing, the larger their stakes. Similar results (not reported) obtain when interacting CEO ownership with the hightech dummy.

The importance of ownership may well have changed over the period, so we estimate tests of differences in slopes between 1996-8 and 1999-2000 (not reported). In 1999-2000, the direct link between pre-IPO equity stakes and how aggressively CEOs bargain over the offer price (as evidenced by lower initial returns) was significantly stronger $(p=1 \%)$. In contrast, the effect of VC ownership on underpricing appears to be concentrated in 1996-8, while corporate and investment bank ownership show no significant variation over time in their influence on initial returns.

The negative relation between investment bank ownership and initial returns in [7] lends support to the agency hypothesis of Baron (1982) and Loughran and Ritter (2001b): if underpricing is in part caused by an agency conflict, it is not surprising that it should be lower when investment banks are shareholders and so when interests are better aligned. Our finding on this point contrasts with the earlier result of Muscarella and Vetsuypens (1989) that investment banks underwriting their own IPOs in the 1970s and 1980s suffered as much underpricing as other issuers. Alternatively, recall that investment bank ownership includes all bank-held stakes, not just those held by underwriters. Interacting the investment bank ownership variable with a dummy variable equaling one when one (or more) of the banks acts as an underwriter yields a statistically insignificant coefficient ( $p=54 \%$, results not reported). Thus, bank ownership reduces underpricing whether or not the bank is involved in marketing and pricing the issue. It seems plausible, therefore, that greater bank ownership reduces underpricing for the same reason that greater VC ownership reduces underpricing: because it pays more to do so. 
Model [8] uses the Herfindahl measure of ownership concentration in place of the individual stake variables. Its coefficient is negative and significant $(p=1.2 \%)$, confirming our conjecture that greater ownership concentration serves to increase offer prices and reduce underpricing. The effect is significantly stronger in 1999-2000 ( $p=2.0 \%$; not shown).

The summary data provided earlier illustrated that the frequency and magnitude of secondary sales declined sharply in 1999-2000. Models [7]-[9] include the participation ratio alongside the ownership variables and find a negative and generally significant association between underpricing and overall secondary sales (normalized by pre-IPO shares outstanding), confirming the earlier results of Habib and Ljungqvist (2001). In models [10] and [11] we disaggregate the participation ratio into sales by insiders as a group ([10]) and sales by CEOs, other corporations, VCs, and investment banks ([11]). The difference between the overall participation ratio and these disaggregated measures captures sales by other pre-IPO shareholders who are not VCs, banks, or corporations, nor represented on the board (for instance, ESOPs). We expect such 'other' pre-IPO shareholders to have less influence on IPO pricing decisions, and therefore predict that the disaggregated measures in [10] and [11] have a larger effect on underpricing than the overall participation ratio used in [7]-[9].

The coefficient estimates bear this out. Underpricing is significantly lower, the greater are sales by insiders as a group ( $p=5 \%$ in [10]), and the magnitude of this effect is more than twice that of the overall participation ratio in [7]-[9]. Breaking out the effects of sales by individual parties, model [11] shows that underpricing correlates negatively with the size of sales for each type of owner, but that once again the role of the venture capitalist is of greatest importance $(p=0.7 \%)$. The VC effect is large in economic magnitude. Going from no VC sales to its maximum, underpricing falls from $33.8 \%$ to $19.8 \%$, holding all other covariates in model [10] at 
their sample means. Controlling separately for the relation between insider sales and underpricing in 1999-2000, we find no evidence of a change over time (results not reported).

Having controlled for the firm and offer characteristics we know to have changed during the dot-com bubble, it is revealing to compare the coefficients estimated for the high-tech, internet, and bubble dummies to their counterparts in the simple regression reported at the beginning of this section. The coefficients for both the high-tech and internet dummy variables, while remaining statistically significant at the 5\% and $1 \%$ level, respectively, have now declined by more than $60 \%$ in magnitude. Similarly, the coefficient for the bubble dummy, after controlling for additional effects, is less than half its former magnitude. In other words, after controlling for firm characteristics, transaction characteristics, ownership structure, and insider selling, the difference in underpricing between the dot-com bubble and the 1996-1998 period is much reduced.

\section{Robustness tests}

\subsection{Reverse causality}

We have interpreted the dramatic decrease in insider sales over the sample period as leading to a reduction in owners' incentives to bargain effectively for a higher offer price. Thus, regressions [10] and [11] treat the insider sales variables as exogenous with respect to underpricing. It is possible, however, that causality runs the other way: owners who expect underpricing to be high, due to the state of the IPO market, may decide to sell fewer or no shares in their IPO. In that case, the insider sales variables are endogenous to expected underpricing and so, possibly, to realized underpricing - the LHS variable in [10] and [11]. We can thus not be sure whether the coefficients reported in [10] and [11] are estimated consistently using OLS.

\footnotetext{
${ }^{15}$ The level of pre-IPO inside ownership and its breakdown should be predetermined and so unaffected by expected underpricing. Thus, we have no reason to expect the coefficients in [7]-[9] to be inconsistently estimated.
} 
To test for consistency, we perform a Durbin-Wu-Hausman (DWH) test [Davidson and MacKinnon (1993) pp. 237f]. As an instrument, we use the average initial return of all IPOs in the same Fama-French industry as sample firm $i$, measured over the 3 months up to the date of $i$ 's first S.E.C. filing. We refer to this variable as lagged underpricing. Given that underpricing is quite persistent over periods of 3 months [Lowry and Schwert (2001)], this instrument may be a good proxy for the level of underpricing insiders expected when they decided on their secondary sales. Since we only have one instrument, we cannot separately test the consistency of sales by each owner category in [11]. Instead, we focus on aggregate insider sales in [10].

Lagged underpricing has the expected negative effect on insider sale decisions $(p=0.5 \%)$, without being correlated with the residuals of the underpricing regression [10]. It thus appears to be a valid instrument. The DWH test statistic of $F_{1,2378}=2.63$ is not significant ( $p=10.5 \%$ ), so we cannot reject the null hypothesis that the OLS estimate for insider sales reported in Table 6 is consistent.

\subsection{Endogeneity considerations}

The underpricing regressions in [7]-[11] treat both underwriter choice and the degree of price revisions as exogenous. However, estimation of model [5] in Table 5 suggests that underwriter choice is better treated as endogenous to a firm's characteristics. Moreover, the Benveniste-Spindt framework suggests that price revisions and underpricing be modeled simultaneously, as the underwriter's pricing decision depends on the price of inducing truthful revelation of information during the bookbuilding effort. Therefore, we estimate a two-stage model that treats both underwriter choice and price revisions in the underpricing regression as endogenous. We use the predicted values for underwriter ranks and price revisions from models [5] and [6] in Table 5, 
respectively, in the model [11] specification of the underpricing regression. ${ }^{6}$ Column [12] in Table 6 reports the results.

A comparison of the OLS coefficients in [11] and the 2SLS coefficients in [12] reveals little change in the influence of insider selling and the firm characteristics, so our previous results for these variables appear robust. When treated as potentially endogenous, underwriter reputation switches sign, to having a negative relation with underpricing, but remains statistically insignificant. Allowing the effect of underwriter reputation to have changed in 1999-2000 (not reported) does not alter this finding. This result lends further support to the interpretation that underwriter prestige influences the degree of information production during bookbuilding, rather than having a direct certification effect on underpricing.

Of the two price revision terms, only the positive-only term is significant in the 2SLS estimates. This implies that, controlling for the simultaneity of price revisions and underpricing, underwriters adjust offer prices fully to negative information and partially to positive information.

The primary changes in the 2SLS model concern the coefficients for internet IPOs and the bubble years: both drop sharply in magnitude and neither is significant at $5 \%$ or better. By implication, the significant coefficient estimated for internet IPOs in the OLS model [11] may simply reflect their greater degree of information production (see models [1]-[4] and [6] in Table 5) which in turn has to be 'paid for' with increased underpricing. Controlling for this, internet IPOs are no more underpriced than other offerings.

\subsection{Parameter stability}

The regression models in Tables 5 and 6 assume that the effects of the ownership and selling characteristics and the bubble dummy variable can be separately identified. To shed light on this,

\footnotetext{
${ }^{16}$ The positive-only term is instrumented from the first-stage predicted values of the price revisions in [6].
} 
we have re-estimated the regression models during the pre-bubble years 1996-1998. Though not reported, we continue to find that underpricing is higher, the less equity VCs $(p=0.4 \%)$ and corporates $(p=3.9 \%)$ hold, the less insiders as a group sell at the IPO $(p=9.4 \%)$, and especially the less VCs sell ( $p=2.2 \%)$. The associated coefficients are not significantly different, as a group, from those reported in Table 6. Thus, there appears to be enough cross-sectional variation in the ownership and selling characteristics even in the earlier years to identify their effects on initial returns.

\subsection{Omitted variable bias}

It is conceivable that we have omitted a variable related to both underpricing and pre-IPO ownership structure and/or insider selling behavior, in which case the association we document could be driven by the omitted variable. For example, say the firms going public in 1999-2000 were more dependent on external capital before the IPO than companies going public in the earlier years. This may explain why firms in 1999-2000 were more frequently VC-backed, and why ownership was more fragmented in general. We find some support for this conjecture: companies that have lower revenues and fewer sales and that go public primarily to fund operating expenses, are associated with significantly more fragmented ownership (not reported). At the same time, such firms may have been inherently harder to value, leading to larger underpricing.

As this example illustrates, it is important to control for the type of firm going public. The variables we use for this purpose - use of proceeds, log age, and industry - may not capture all dimensions of firm type. We have investigated three others - log sales, log assets, and pre-IPO profitability - but none of them is significant in the underpricing regressions. 


\section{Conclusion}

The data and analysis presented in this paper illustrate that the aberrant pricing behavior witnessed during the dot-com bubble can be at least partially accounted for by marked changes in pre-IPO ownership structure and insider selling behavior over the same period. After controlling for these changes, the 1999-2000 period is noteworthy more for these changes than for the simple fact that valuations and underpricing simultaneously skyrocketed. We have not attempted to explain this massive restructuring of incentives.

It is conceivable that the firms going public during this period were fundamentally riskier or less transparent than their predecessors. If insiders expected these firm characteristics to translate into larger discounts, a rational response would have been to diminish their exposure to the IPO discount and thereby diminish their interest in bargaining for a higher offer price. Thus greater

uncertainty and rational expectations regarding its consequences might have worked hand-in-glove to amplify initial returns. Our findings and those of Loughran and Ritter (2001b) provide some support for this 'changing composition' conjecture.

It is also worth noting that while insider percentage holdings declined over the sample period, offer prices increased. The net effect was for the dollar value of insider holdings (valued at the offer price) to increase monotonically over the sample period. Thus insiders' expected utility from bargaining more aggressively over the offer price may have declined at the margin with their growing wealth. This might be interpreted as a non-behavioral version of the Loughran and Ritter (2001b) complacency argument.

Alternatively, the high visibility of a severely discounted IPO might serve a marketing function. Demers and Lewellen (2001) provide support for this hypothesis by showing that firms with larger initial returns received more press coverage and, in the case of internet firms, attracted 
more traffic at their websites. Stoughton et al. (2001) formalize this idea in a model where highquality firms distinguish themselves, and thereby build product market share, by incurring the indirect cost of underpricing and subjecting themselves to the scrutiny of secondary market investors engaged in costly information production. One prediction generated by the model is that high-quality firms in industries subject to network externalities are more likely to satisfy the necessary conditions for going public. These firms simultaneously will be characterized by higher insider equity retention.

Finally, it is possible that neither standard rational nor behavioural models can fully explain investor behaviour in 1999-2000. Suppose, for whatever reason, that investors were simply optimistic in the extreme. Issuing firm insiders might rationally have chosen to go public, sell relatively little of the firm, while hoping to liquidate their stakes after having them bid up to astronomical levels but before the bubble burst. Investment banks and their analysts might have exploited their investor relationships to fan the flames of excessive optimism in spite of the threat to their reputations. This story is consistent with the spirit of the recent S.E.C. investigation of the investment banking industry but for researchers it obviously raises at least as many questions as it might answer. 


\section{References}

Aggarwal, R., Prabhala, N.R., Puri, M., 2001. Institutional allocation in initial public offerings: empirical evidence. Journal of Finance, forthcoming.

Allen, F., Faulhaber, G.R., 1989. Signalling by underpricing in the IPO market. Journal of Financial Economics 23, 303-323.

Baker, M.P., Gompers, P., 1999. Executive ownership and control in newly public firms: The role of venture capitalists. Unpublished working paper. Harvard Business School.

Baron, D.P., 1982. A model of the demand for investment banking advising and distribution services for new issues. Journal of Finance 37, 955-976.

Benveniste, L.M., Spindt, P.A., 1989. How investment bankers determine the offer price and allocation of new issues. Journal of Financial Economics 24, 343-61.

Benveniste, L.M., Wilhelm, W.J., 1990. A comparative analysis of IPO proceeds under alternative regulatory environments. Journal of Financial Economics 28, 173-207.

Benveniste, L.M., Busaba, W., Wilhelm, W.J., 2002. Information externalities and the role of underwriters in primary equity markets. Journal of Financial Intermediation, forthcoming.

Benveniste, L.M., Ljungqvist, A.P., Wilhelm, W.J., Yu, X., 2001. Evidence of information spillovers in the production of investment banking services. Unpublished working paper. New York University.

Biais, B., Bossaerts, P., Rochet, J.-C., 2000. An optimal IPO mechanism. Review of Economic Studies, forthcoming.

Booth, J.R., Smith, R., 1986. Capital raising, underwriting and the certification hypothesis. Journal of Financial Economics 15, 261-281.

Carter, R.B., Manaster, S., 1990. Initial public offerings and underwriter reputation. Journal of Finance 45, 1045-1067.

Davidson, R., MacKinnon, J.G., 1993. Estimation and Inference in Econometrics. Oxford University Press.

Demers, E.A., Lewellen, K., 2001. The marketing role of IPOs: evidence from internet stocks. Unpublished working paper. University of Rochester.

Fama, E.F., French, K.R., 1997. Industry costs of equity. Journal of Financial Economics 43, 153-194.

Habib, M.A., Ljungqvist, A.P., 2001. Underpricing and entrepreneurial wealth losses: theory and evidence. Review of Financial Studies 14, 433-458. 
Hanley, K., 1993. The underpricing of initial public offerings and the partial adjustment phenomenon. Journal of Financial Economics 34, 231-50.

Ljungqvist, A.P., Wilhelm, W.J., 2001. IPO allocations: discriminatory or discretionary? Journal of Financial Economics, forthcoming.

Loughran, T., Ritter, J.R., 2001a. Why don't issuers get upset about leaving money on the table in IPOs? Review of Financial Studies, forthcoming.

Loughran, T., Ritter, J.R., 2001b. Why has IPO underpricing increased over time? Unpublished working paper. University of Florida.

Lowry, M., Schwert, G.W., 2001. IPO market cycles: bubbles or sequential learning? Journal of Finance, forthcoming

Muscarella, C.J., Vetsuypens, M.R., 1989. A simple test of Baron's model of IPO underpricing. Journal of Financial Economics 24, 125-135.

Rock, K., 1986. Why new issues are underpriced. Journal of Financial Economics 15, 187-212.

Stoughton, N.M., Wong, K.P., Zechner, J., 2001. IPOs and product quality. Journal of Business 74, 375-408.

Welch, I., 1989. Seasoned offerings, imitation costs, and the underpricing of initial public offerings. Journal of Finance 44, 421-449.

Welch, I., 1992. Sequential sales, learning and cascades. Journal of Finance 47, 695-732. 
Table 1. Descriptive characteristics of sample firms.

Internet companies are classified as in Loughran and Ritter (2001b), with minor modifications. High-tech companies are active in SIC codes 3571, 3572, 3575, 3577, 3578 (computer hardware), 3661, 3663, 3669 (communications equipment), 3674 (electronics), 3812 (navigation equipment), 3823, 3825, 3826, 3827, 3829 (measuring and controlling devices), 4899 (communication services), and 7370, 7371, 7372, 7373, 7374, 7375, 7378, and 7379 (software); see Loughran and Ritter (2001b). Age is IPO year minus founding date. We lack age data for 3 companies. Accounting data is from SDC. EPS data is hand-cleaned using S.E.C. filings, 10-Ks etc. We test the significance of the changes over time by regressing each characteristic on an annual time trend $t$, and report, in the last column, the significance level of the coefficient estimated for $t$. We use OLS to test for trends in means, median regressions to test for trends in medians, and probit regressions to test for trends in binary variables. ${ }^{* * *},{ }^{* *},{ }^{*}$ denote significance at $1 \%, 5 \%$ or $10 \%$ (two-sided), respectively. Lack of significance is indicated as -.

\begin{tabular}{|c|c|c|c|c|c|c|c|c|}
\hline & & $\begin{array}{r}1996 \\
-2000 \\
\end{array}$ & 1996 & 1997 & 1998 & 1999 & 2000 & $\begin{array}{c}\text { Trend } \\
\text { sig. ? }\end{array}$ \\
\hline No. of sample firms & & 2,399 & 718 & 500 & 320 & 487 & 374 & \\
\hline Fraction internet companies & & 20.22 & 2.79 & 4.60 & 12.50 & 54.83 & 36.10 & $* * *$ \\
\hline Fraction high-tech companies & & 37.35 & 33.29 & 29.20 & 28.13 & 49.69 & 47.86 & $* * *$ \\
\hline \multirow[t]{5}{*}{ Age } & Mean & 13.6 & 14.2 & 16.1 & 17.6 & 9.9 & 10.7 & $* * *$ \\
\hline & St.dev. & 19.9 & 20.0 & 20.6 & 23.3 & 17.7 & 17.3 & \\
\hline & Min & 0 & 0 & 0 & 0 & 0 & 0 & \\
\hline & Median & 7 & 8 & 9 & 9 & 5 & 6 & $* * *$ \\
\hline & $\operatorname{Max}$ & 182 & 176 & 121 & 156 & 182 & 138 & \\
\hline \multirow[t]{5}{*}{ Revenue } & Mean $(\$ m)$ & 208.6 & 169.4 & 137.7 & 182.7 & 338.2 & 232.2 & $* * *$ \\
\hline & St.dev. & $1,597.0$ & $1,041.3$ & 371.6 & 669.1 & $2,909.0$ & $1,638.8$ & \\
\hline & Min & 0.0 & 0.0 & 0.0 & 0.0 & 0.0 & 0.0 & \\
\hline & Median & 20.4 & 22.8 & 29.6 & 26.9 & 13.9 & 10.6 & $* * *$ \\
\hline & $\operatorname{Max}$ & 51,058 & 21,413 & 4,384 & 7,023 & 51,058 & 25,426 & \\
\hline \multirow[t]{6}{*}{ Book value of assets } & Mean $(\$ \mathrm{~m})$ & 475.5 & 268.3 & 443.8 & 308.0 & 383.2 & $1,122.5$ & $* * *$ \\
\hline & St.dev. & $5,849.5$ & $2,166.0$ & $4,450.7$ & $1,415.2$ & $2,248.81$ & $12,882.9$ & \\
\hline & Min & 0.1 & 0.1 & 0.2 & 0.2 & 0.2 & 0.2 & \\
\hline & Median & 25.0 & 17.6 & 23.3 & 28.6 & 25.1 & 34.3 & $* * *$ \\
\hline & $\operatorname{Max}$ & 225,232 & 41,304 & 79,933 & 13,155 & 34,554 & 225,232 & \\
\hline & No. w/ complete data & 2,132 & 616 & 442 & 259 & 463 & 352 & \\
\hline \multirow[t]{6}{*}{ Book value of equity } & Mean $(\$ m)$ & 57.9 & 35.3 & 32.6 & 51.3 & 65.3 & 124.1 & $* *$ \\
\hline & St.dev. & 566.9 & 305.4 & 186.0 & 323.8 & 528.5 & $1,134.3$ & \\
\hline & Min & -958.5 & -753.2 & -423.7 & -623.7 & -958.5 & -603.0 & \\
\hline & Median & 3.5 & 3.9 & 5.2 & 4.8 & 1.0 & -0.4 & $* * *$ \\
\hline & $\operatorname{Max}$ & 14,027 & 5,237 & 2,395 & 3,940 & 7,173 & 14,027 & \\
\hline & No. w/ complete data & 2,129 & 618 & 444 & 253 & 460 & 354 & \\
\hline \multirow[t]{6}{*}{ Net income after taxes } & Mean $(\$ \mathrm{~m})$ & -2.5 & 1.7 & -0.3 & 2.6 & -5.2 & -13.3 & $* * *$ \\
\hline & St.dev. & 73.8 & 48.8 & 59.2 & 29.3 & 119.5 & 71.1 & \\
\hline & Min - & $-1,556.3$ & -867.0 & -870.7 & -131.1 & $-1,556.3$ & -709.4 & \\
\hline & Median & -0.6 & 0.6 & 1.0 & 0.3 & -4.9 & -8.5 & $* * *$ \\
\hline & $\operatorname{Max}$ & $1,741.0$ & 723.1 & 336.0 & 189.4 & $1,741.0$ & 617.0 & \\
\hline & No. w/ complete data & 2,071 & 611 & 444 & 238 & 444 & 334 & \\
\hline Fraction $w /$ EPS $\leq 0$ & & 54.61 & 43.18 & 38.40 & 43.44 & 76.39 & 79.41 & $* * *$ \\
\hline
\end{tabular}


Table 2. Descriptive characteristics of sample transactions.

Gross proceeds exclude the over-allotment option. The main use of proceeds is identified manually, using the numerical breakdown of intended uses if provided in a prospectus, or else based on a reading of the "Use of Proceeds" section. If the wording does not allow us to rank intended uses, we treat the company as not having an identifiable main use of proceeds. Underwriter rankings are based on the Loughran-Ritter (2001b) update of the Carter-Manaster (1990) tombstone measure. Syndicate size is the number of banks making up the syndicate. The expected offer price is computed as the midpoint of the indicate filing range. Price revisions are the percentage update between the expected and final offer price. The initial return is the first-day close over the offer price, minus one. Directed Share Programs reserve shares for preferential allocation to individuals chosen by the issuer. We lack prospectuses and information regarding DSPs for two firms.

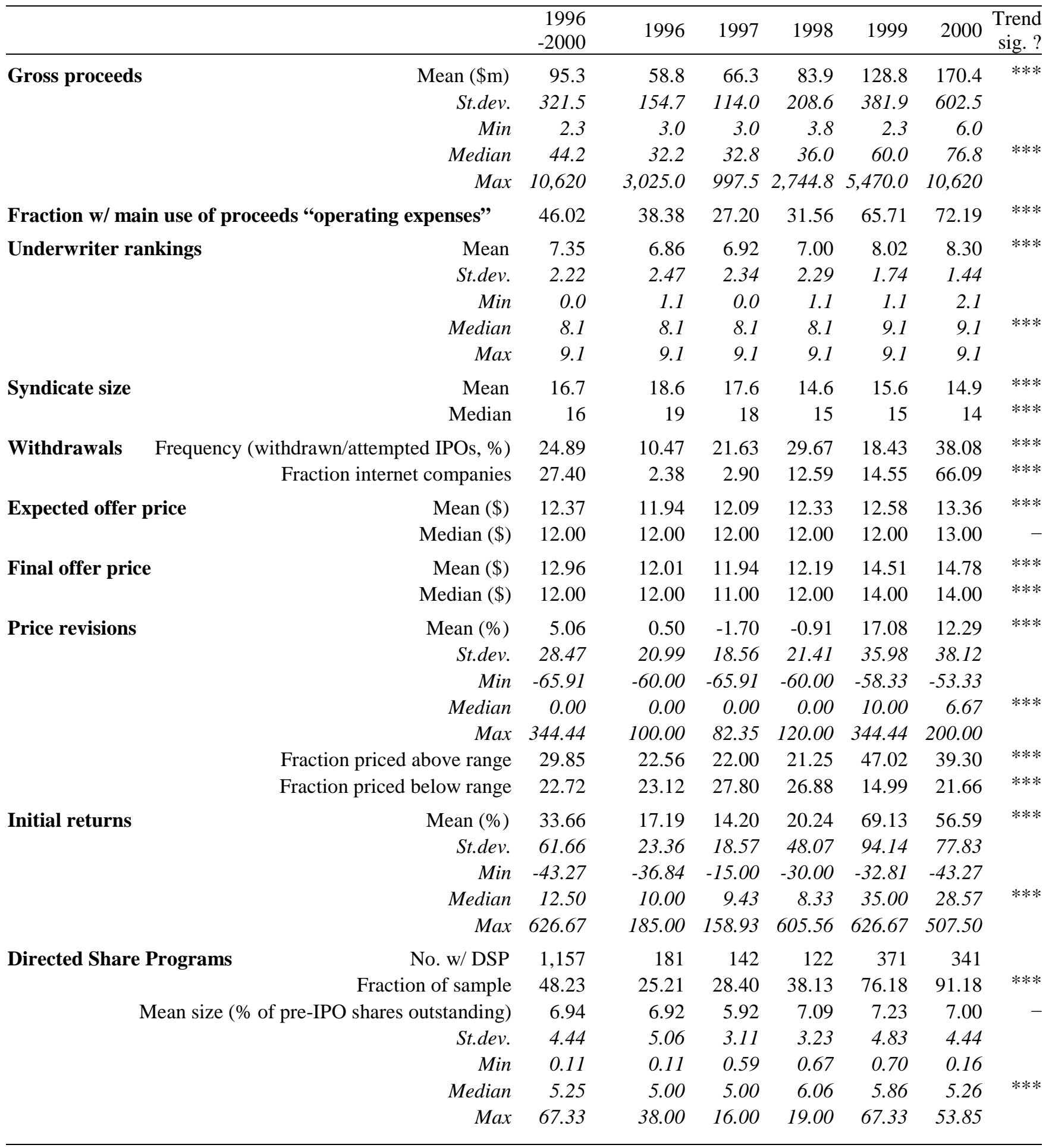


Table 3. Ownership structure pre-IPO.

Ownership data is hand-collected from IPO prospectuses and is available for 2,397 of the 2,399 sample firms. 'Insiders' are directors and executive officers as a group. VC backing information comes from the prospectuses and includes backing by either venture capitalists or private equity (middle-market, buy-out, merchant banking) funds. Corporate shareholders are bona fide operating companies and exclude shell companies owned by founders or executives. Ownership concentration is measured using a Herfindahl index, here computed as the sum of the squared equity stakes held by CEOs, VCs, corporates, and investment banks. We lack prospectuses and thus ownership data for two firms.

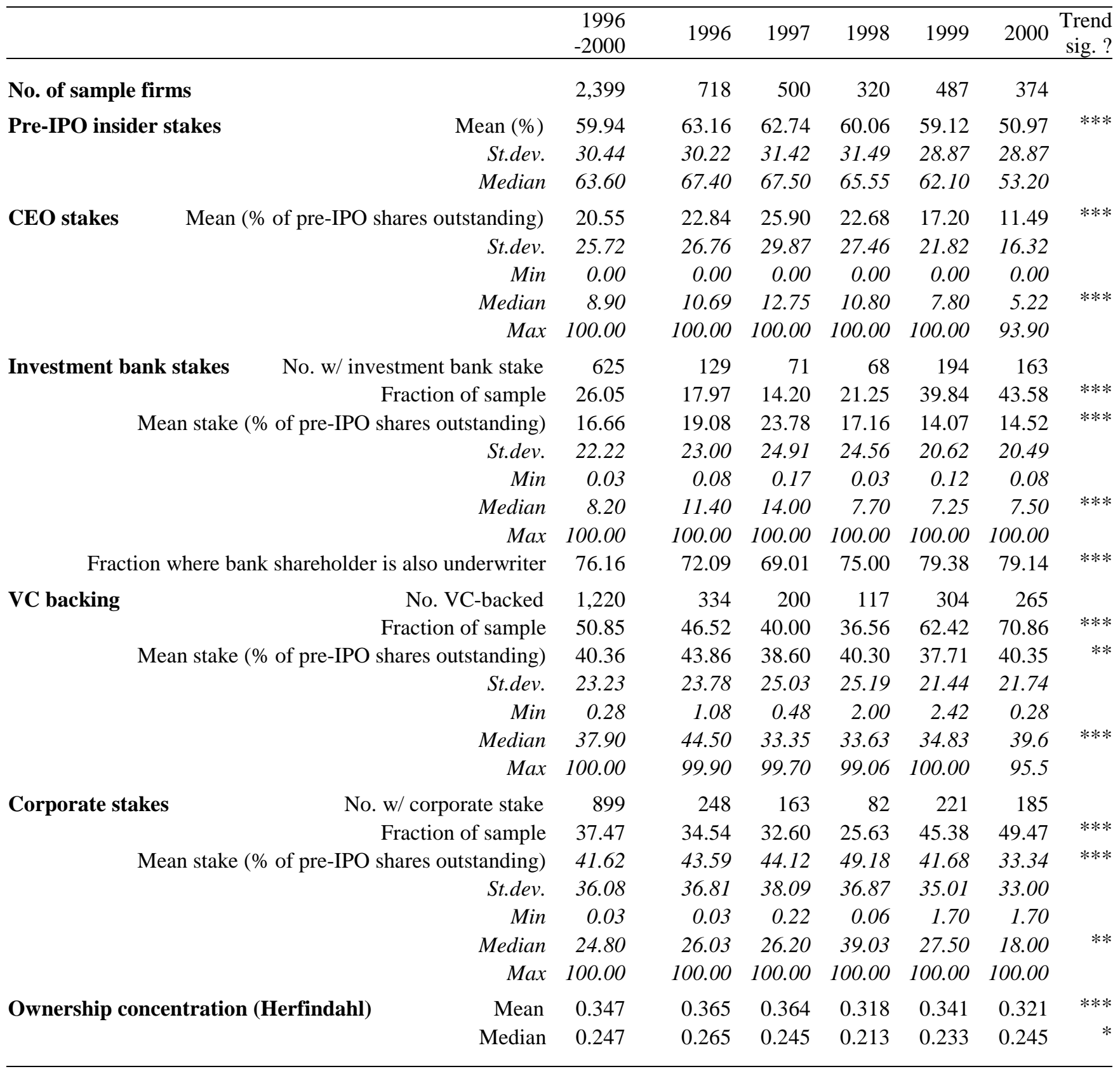


Table 4. Insider sales at the IPO.

Secondary sales denote sales of existing shares. Incidents of CEOs, VCs, corporates or investment banks selling shares at the IPO are identified from the prospectuses. 'Insiders' are directors and executive officers as a group. We lack prospectuses and thus ownership data for two firms.

\begin{tabular}{|c|c|c|c|c|c|c|c|}
\hline & $\begin{array}{r}1996 \\
-2000 \\
\end{array}$ & 1996 & 1997 & 1998 & 1999 & 2000 & $\begin{array}{r}\text { Trend } \\
\text { sig. ? }\end{array}$ \\
\hline Fraction w/ secondary sales & 27.47 & 35.79 & 33.60 & 32.81 & 19.51 & 9.09 & $* * *$ \\
\hline Mean (\% of pre-IPO shares outstanding) & 3.58 & 4.67 & 5.33 & 3.90 & 2.04 & 0.88 & $* * *$ \\
\hline St.dev. & 9.80 & 10.42 & 12.31 & 10.88 & 7.40 & 4.11 & \\
\hline Min & 0.00 & 0.00 & 0.00 & 0.00 & 0.00 & 0.00 & \\
\hline Median & 0.00 & 0.00 & 0.00 & 0.00 & 0.00 & 0.00 & $\begin{array}{ll}- \\
-\end{array}$ \\
\hline $\operatorname{Max}$ & 100.00 & 100.00 & 100.00 & 100.00 & 100.00 & 37.00 & \\
\hline Secondary sales as a fraction of offer size & 7.71 & 9.75 & 10.40 & 9.40 & 4.85 & 2.51 & $* * *$ \\
\hline Key shareholders selling & 9.71 & 14.76 & 12.20 & 11.88 & 4.93 & 1.07 & $* * *$ \\
\hline Fraction of VC-backed IPOs w/ VC sales at IPO & 14.51 & 23.05 & 23.00 & 23.93 & 6.25 & 2.64 & $* * *$ \\
\hline Fraction of bank-backed IPOs w/ bank sales at IPO & 14.24 & 23.26 & 33.80 & 23.53 & 7.73 & 2.45 & $* * *$ \\
\hline Fraction of corporate-backed IPOs w/ corporate sales at IPO & 19.91 & 27.82 & 30.06 & 26.83 & 10.86 & 8.11 & $* * *$ \\
\hline \multirow[t]{5}{*}{ Post-IPO insider stakes } & 43.30 & 43.91 & 42.79 & 42.03 & 45.90 & 40.53 & - \\
\hline & 22.75 & 22.26 & 22.94 & 23.36 & 22.52 & 22.90 & \\
\hline & 0.00 & 0.00 & 0.00 & 0.00 & 0.00 & 0.00 & \\
\hline & 45.20 & 45.30 & 45.15 & 45.53 & 49.00 & 42.20 & - \\
\hline & 96.90 & 96.90 & 90.07 & 89.90 & 88.00 & 89.80 & \\
\hline
\end{tabular}


Table 5. Least-squares price revision regressions.

The dependent variable in regressions [1]-[4] and [6] is the price revision from the midpoint of the initial filing range to the offer price, relative to the midpoint. The dependent variable in regression [5] is Loughran and Ritter's (2001b) update of the Carter-Manaster investment bank ranking variable. Firm and offer characteristics are defined as in Tables 1-4. [1]-[4] are estimated using OLS. [6] is estimated using 2SLS, with [5] being the first stage. Standard errors are adjusted for time clustering by assuming that observations are independent for companies at different points in time, but not necessarily for companies which go public in the same month. They are more conservative than White (1980) standard errors. ${ }^{* * *},{ }^{* * *},{ }^{*}=$ significant at $1 \%, 5 \%$ or $10 \%$ (two-sided), respectively. The number of observations is 2,391. (We lack age data for three firms, first-day prices for three firms, and ownership data for two firms.)

\begin{tabular}{|c|c|c|c|c|c|c|}
\hline \multirow{3}{*}{ Dependent variable: } & {$[1]$} & [2] & [3] & [4] & & [6] \\
\hline & $\begin{array}{c}\text { Price } \\
\text { revision }\end{array}$ & $\begin{array}{l}\text { Price } \\
\text { revision }\end{array}$ & $\begin{array}{c}\text { Price } \\
\text { revision }\end{array}$ & $\begin{array}{l}\text { Price } \\
\text { revision }\end{array}$ & $\begin{array}{l}\text { Investment } \\
\text { bank } \\
\text { ranking }\end{array}$ & $\begin{array}{l}\text { Price } \\
\text { revision }\end{array}$ \\
\hline & OLS & OLS & OLS & OLS & OLS & 2SLS \\
\hline \multicolumn{7}{|l|}{ Pre-IPO ownership } \\
\hline CEO stake & $\begin{array}{l}0.004 \\
0.017\end{array}$ & & & & & \\
\hline Corporate stake & $\begin{array}{r}-0.014 \\
0.019\end{array}$ & & & & & \\
\hline VC stake & $\begin{array}{r}-0.014 \\
0.019\end{array}$ & & & & & \\
\hline Investment bank stake & $\begin{array}{c}-0.048^{*} \\
0.026\end{array}$ & & & & & \\
\hline Pre-IPO ownership concentration & & $\begin{array}{r}-0.009 \\
0.014\end{array}$ & & & & \\
\hline \multicolumn{7}{|l|}{ Insider sales at the IPO } \\
\hline Size of insider sales & & & $\begin{array}{l}0.023 \\
0.061\end{array}$ & & & \\
\hline Size of CEO sales & & & & $\begin{array}{l}0.304^{*} \\
0.158\end{array}$ & $\begin{array}{l}2.942^{* *} \\
1.159\end{array}$ & $\begin{array}{l}0.320^{* *} \\
0.159\end{array}$ \\
\hline Size of VC sales & & & & $\begin{array}{l}0.154^{*} \\
0.084\end{array}$ & $\begin{array}{c}-2.452^{* * *} \\
0.778\end{array}$ & $\begin{array}{l}0.170^{* *} \\
0.082\end{array}$ \\
\hline Size of investment bank sales & & & & $\begin{array}{r}-0.037 \\
0.177\end{array}$ & $\begin{array}{l}0.331 \\
1.331\end{array}$ & $\begin{array}{r}-0.005 \\
0.182\end{array}$ \\
\hline Size of corporate sales & & & & $\begin{array}{c}-0.089^{*} \\
0.050\end{array}$ & $\begin{array}{c}-1.529^{* * *} \\
0.407\end{array}$ & $\begin{array}{c}-0.089^{*} \\
0.050\end{array}$ \\
\hline \multicolumn{7}{|l|}{ Firm and offer characteristics } \\
\hline $\ln (1+$ age $)$ & $\begin{array}{c}-0.013^{* *} \\
0.006\end{array}$ & $\begin{array}{c}-0.012^{* *} \\
0.006\end{array}$ & $\begin{array}{c}-0.012^{* *} \\
0.006\end{array}$ & $\begin{array}{c}-0.013^{* *} \\
0.006\end{array}$ & $\begin{array}{l}0.075^{* *} \\
0.034\end{array}$ & $\begin{array}{c}-0.012^{*} \\
0.006\end{array}$ \\
\hline$=1$ if high-tech industry & $\begin{array}{l}0.027^{* *} \\
0.012\end{array}$ & $\begin{array}{l}0.027^{* * *} \\
0.013\end{array}$ & $\begin{array}{l}0.027^{* * *} \\
0.013\end{array}$ & $\begin{array}{l}0.027^{* *} \\
0.013\end{array}$ & $\begin{array}{l}0.310^{* * * *} \\
0.072\end{array}$ & $\begin{array}{l}0.029^{* *} \\
0.013\end{array}$ \\
\hline$=1$ if internet company & $\begin{array}{l}0.128^{* * *} \\
0.020\end{array}$ & $\begin{array}{l}0.128^{* * *} \\
0.020\end{array}$ & $\begin{array}{l}0.128^{* * * *} \\
0.020\end{array}$ & $\begin{array}{l}0.128^{* * *} \\
0.020\end{array}$ & $\begin{array}{l}0.229^{* * *} \\
0.072\end{array}$ & $\begin{array}{l}0.130^{* * * *} \\
0.020\end{array}$ \\
\hline Investment bank ranking & $\begin{array}{l}0.021^{\text {*** }} \\
0.004\end{array}$ & $\begin{array}{l}0.020^{* * * *} \\
0.004\end{array}$ & $\begin{array}{l}0.020^{* * * *} \\
0.004\end{array}$ & $\begin{array}{l}0.020^{* * *} \\
0.004\end{array}$ & & $\begin{array}{l}0.013^{* *} \\
0.005\end{array}$ \\
\hline Syndicate size & $\begin{array}{c}-0.001^{* *} \\
0.001\end{array}$ & $\begin{array}{c}-0.002^{* * * *} \\
0.001\end{array}$ & $\begin{array}{c}-0.002^{* * *} \\
0.001\end{array}$ & $\begin{array}{c}-0.002^{* * * *} \\
0.001\end{array}$ & $\begin{array}{l}0.011^{* *} \\
0.005\end{array}$ & $\begin{array}{c}-0.001^{*} \\
0.001\end{array}$ \\
\hline$=1$ if venture backed & & & & & $\begin{array}{l}0.925^{* * *} \\
0.081\end{array}$ & \\
\hline $\ln$ (filing amount) & & & & & $\begin{array}{l}1.388^{* * * *} \\
0.069\end{array}$ & \\
\hline
\end{tabular}




\begin{tabular}{|c|c|c|c|c|c|c|}
\hline \multirow{3}{*}{ Dependent variable: } & [1] & [2] & [3] & [4] & & [6] \\
\hline & $\begin{array}{l}\text { Price } \\
\text { revision }\end{array}$ & $\begin{array}{l}\text { Price } \\
\text { revision }\end{array}$ & $\begin{array}{l}\text { Price } \\
\text { revision }\end{array}$ & $\begin{array}{l}\text { Price } \\
\text { revision }\end{array}$ & $\begin{array}{l}\text { Investment } \\
\text { bank } \\
\text { ranking }\end{array}$ & $\begin{array}{l}\text { Price } \\
\text { revision }\end{array}$ \\
\hline & OLS & OLS & OLS & OLS & OLS & 2SLS \\
\hline \multicolumn{7}{|l|}{ Spillover variables } \\
\hline \multirow[t]{2}{*}{ Industry return } & $0.287^{* * *}$ & $0.287^{* * *}$ & $0.286^{* * *}$ & $0.286^{* * *}$ & -0.139 & $0.280^{* * * *}$ \\
\hline & 0.042 & 0.042 & 0.042 & 0.042 & 0.158 & 0.041 \\
\hline \multirow[t]{2}{*}{ Mean contemporary underpricing } & $0.139^{* * *}$ & $0.139^{* * * *}$ & $0.139^{* * *}$ & $0.140^{* * *}$ & 0.078 & $0.141^{* * *}$ \\
\hline & 0.028 & 0.028 & 0.028 & 0.028 & 0.118 & 0.028 \\
\hline \multicolumn{7}{|l|}{ "Bubble" } \\
\hline \multirow[t]{2}{*}{$=1$ if in 1999 or 2000} & -0.023 & -0.025 & -0.025 & -0.023 & -0.083 & -0.014 \\
\hline & 0.021 & 0.021 & 0.020 & 0.020 & 0.087 & 0.021 \\
\hline \multirow[t]{2}{*}{ Constant } & $-0.148^{* * *}$ & $-0.145^{* * *}$ & $-0.147^{* * *}$ & $-0.146^{* * *}$ & $1.186^{* * *}$ & $-0.112^{* * *}$ \\
\hline & 0.024 & 0.022 & 0.022 & 0.021 & 0.246 & 0.028 \\
\hline$R^{2} /$ McFadden's $R^{2}$ & $22.08 \%$ & $22.01 \%$ & $22.01 \%$ & $22.15 \%$ & $54.01 \%$ & $21.93 \%$ \\
\hline$F$-test all coeff. $=0$ & $33.09^{* * *}$ & $38.89^{* * *}$ & $37.90^{* * * *}$ & $29.30^{* * * *}$ & $216.76^{* * * *}$ & $29.67^{* * *}$ \\
\hline
\end{tabular}


Table 6. Least-squares underpricing regressions.

The dependent variable in all regressions is the initial return (the first-day closing price relative to the offer price). The participation ratio is the number of secondary shares sold at the IPO normalized by the number of pre-IPO shares outstanding. The dilution factor is the number of primary shares issued normalized by the number of pre-IPO shares outstanding. Price revision ${ }^{+}$equals the price revision between the midpoint of the filing range and the final offer price if positive, and zero otherwise. All other regressors are defined as in Table 5. The 2SLS regression in column [12] uses models [5] and [6] in Table 5 as its first-stage. Standard errors are adjusted for time clustering by assuming that observations are independent for companies at different points in time, but not necessarily for companies which go public in the same month. They are more conservative than White (1980) standard errors. ${ }^{* * * *}$, $* *{ }^{*}=$ significant at $1 \%, 5 \%$ or $10 \%$ (two-sided), respectively. The number of observations is 2,391 . (We lack age data for three firms, first-day prices for three firms, and ownership data for two firms.)

\begin{tabular}{|c|c|c|c|c|c|c|}
\hline Dependent variable: & $\begin{array}{c}{[7]} \\
\text { Initial } \\
\text { return }\end{array}$ & $\begin{array}{c}{[8]} \\
\text { Initial } \\
\text { return }\end{array}$ & $\begin{array}{c}{[9]} \\
\text { Initial } \\
\text { return }\end{array}$ & $\begin{array}{c}{[10]} \\
\text { Initial } \\
\text { return }\end{array}$ & $\begin{array}{c}{[11]} \\
\text { Initial } \\
\text { return }\end{array}$ & $\begin{array}{c}{[12]} \\
\text { Initial } \\
\text { return }\end{array}$ \\
\hline & OLS & OLS & OLS & OLS & OLS & 2 SLS \\
\hline \multicolumn{7}{|l|}{ Pre-IPO ownership } \\
\hline CEO stake & $\begin{array}{r}-0.034 \\
0.033\end{array}$ & $\begin{array}{l}0.016 \\
0.027\end{array}$ & & & & \\
\hline CEO stake $\times$ internet dummy & & $\begin{array}{c}-0.438^{* * * *} \\
0.145\end{array}$ & & & & \\
\hline Corporate stake & $\begin{array}{c}-0.097^{* * *} \\
0.033\end{array}$ & $\begin{array}{c}-0.097^{* * *} \\
0.033\end{array}$ & & & & \\
\hline VC stake & $\begin{array}{c}-0.073^{* * *} \\
0.025\end{array}$ & $\begin{array}{c}-0.072^{* * *} \\
0.025\end{array}$ & & & & \\
\hline Investment bank stake & $\begin{array}{c}-0.107^{* * *} \\
0.039\end{array}$ & $\begin{array}{c}-0.091^{* *} \\
0.041\end{array}$ & & & & \\
\hline Pre-IPO ownership concentration & & & $\begin{array}{c}-0.070^{* *} \\
0.027\end{array}$ & & & \\
\hline \multicolumn{7}{|l|}{ Insider sales at the IPO } \\
\hline Size of insider sales & & & & $\begin{array}{c}-0.155^{* *} \\
0.077\end{array}$ & & \\
\hline Size of CEO sales & & & & & $\begin{array}{r}-0.020 \\
0.130\end{array}$ & $\begin{array}{l}0.068 \\
0.185\end{array}$ \\
\hline Size of VC sales & & & & & $\begin{array}{c}-0.227^{* * *} \\
0.081\end{array}$ & $\begin{array}{c}-0.187^{* * *} \\
0.092\end{array}$ \\
\hline Size of investment bank sales & & & & & $\begin{array}{r}-0.017 \\
0.197\end{array}$ & $\begin{array}{l}0.106 \\
0.202\end{array}$ \\
\hline Size of corporate sales & & & & & $\begin{array}{r}-0.003 \\
0.042\end{array}$ & $\begin{array}{r}-0.056 \\
0.054\end{array}$ \\
\hline Firm and offer characteristics & & & & & & \\
\hline $\ln (1+$ age $)$ & $\begin{array}{c}-0.031^{* * *} \\
0.011\end{array}$ & $\begin{array}{c}-0.031^{* * * *} \\
0.011\end{array}$ & $\begin{array}{c}-0.028^{* *} \\
0.011\end{array}$ & $\begin{array}{c}-0.029^{* *} \\
0.011\end{array}$ & $\begin{array}{c}-0.029^{* *} \\
0.011\end{array}$ & $\begin{array}{c}-0.033^{* *} \\
0.014\end{array}$ \\
\hline Participation ratio & $\begin{array}{r}-0.056 \\
0.035\end{array}$ & $\begin{array}{r}-0.049 \\
0.034\end{array}$ & $\begin{array}{c}-0.068^{* *} \\
0.033\end{array}$ & & & \\
\hline Dilution factor & $\begin{array}{c}-0.038^{* * *} \\
0.012\end{array}$ & $\begin{array}{c}-0.036^{* * * *} \\
0.012\end{array}$ & $\begin{array}{c}-0.035^{* * *} \\
0.011\end{array}$ & $\begin{array}{c}-0.032^{* * * *} \\
0.011\end{array}$ & $\begin{array}{c}-0.032^{* * * *} \\
0.011\end{array}$ & $\begin{array}{c}-0.067^{* * * *} \\
0.014\end{array}$ \\
\hline DSP as $\%$ of offer size & $\begin{array}{l}0.006^{* *} \\
0.003\end{array}$ & $\begin{array}{l}0.006^{* *} \\
0.003\end{array}$ & $\begin{array}{l}0.006^{* * *} \\
0.003\end{array}$ & $\begin{array}{l}0.006^{* *} \\
0.003\end{array}$ & $\begin{array}{l}0.006^{* * *} \\
0.003\end{array}$ & $\begin{array}{l}0.012^{* * *} \\
0.003\end{array}$ \\
\hline$=1$ if main use of proceeds is opex & $\begin{array}{l}0.066^{* *} \\
0.025\end{array}$ & $\begin{array}{l}0.063^{* *} \\
0.025\end{array}$ & $\begin{array}{l}0.063^{* *} \\
0.025\end{array}$ & $\begin{array}{l}0.071^{\text {*** }} \\
0.026\end{array}$ & $\begin{array}{l}0.071^{* * * *} \\
0.026\end{array}$ & $\begin{array}{l}0.092^{* * *} \\
0.032\end{array}$ \\
\hline Investment bank ranking & $\begin{array}{l}0.010 \\
0.006\end{array}$ & $\begin{array}{l}0.009 \\
0.006\end{array}$ & $\begin{array}{l}0.007 \\
0.006\end{array}$ & $\begin{array}{l}0.006 \\
0.006\end{array}$ & $\begin{array}{l}0.006 \\
0.006\end{array}$ & $\begin{array}{r}-0.007 \\
0.007\end{array}$ \\
\hline
\end{tabular}




\begin{tabular}{|c|c|c|c|c|c|c|}
\hline \multirow[t]{2}{*}{ Dependent variable: } & $\begin{array}{l}{[7]} \\
\text { Initial } \\
\text { return }\end{array}$ & $\begin{array}{l}{[8]} \\
\text { Initial } \\
\text { return }\end{array}$ & $\begin{array}{l}{[9]} \\
\text { Initial } \\
\text { return }\end{array}$ & $\begin{array}{l}{[10]} \\
\text { Initial } \\
\text { return }\end{array}$ & $\begin{array}{l}{[11]} \\
\text { Initial } \\
\text { return }\end{array}$ & $\begin{array}{l}{[12]} \\
\text { Initial } \\
\text { return }\end{array}$ \\
\hline & OLS & OLS & OLS & OLS & OLS & $2 \mathrm{SLS}$ \\
\hline Price revision & $0.381^{* * *}$ & $0.382^{* * * *}$ & $0.391^{* * *}$ & $0.388^{* * *}$ & $0.389^{* * *}$ & -0.134 \\
\hline Price revision $^{+}$ & $\begin{array}{l}0.111 \\
0.934^{* * *} \\
0.278\end{array}$ & $\begin{array}{l}0.112 \\
0.929^{* * *} \\
0.278\end{array}$ & $\begin{array}{l}0.111 \\
0.925^{* * *} \\
0.278\end{array}$ & $\begin{array}{l}0.111 \\
0.930^{* * *} \\
0.278\end{array}$ & $\begin{array}{l}0.111 \\
0.928^{* * * *} \\
0.278\end{array}$ & $\begin{array}{l}0.306 \\
1.965^{* * *} \\
0.538\end{array}$ \\
\hline "New economy" & & & & & & \\
\hline$=1$ if high-tech industry & $\begin{array}{l}0.062^{* *} \\
0.024\end{array}$ & $\begin{array}{l}0.064^{* * *} \\
0.024\end{array}$ & $\begin{array}{l}0.060^{* *} \\
0.024\end{array}$ & $\begin{array}{l}0.063^{* *} \\
0.024\end{array}$ & $\begin{array}{l}0.063^{* *} \\
0.024\end{array}$ & $\begin{array}{l}0.058^{* *} \\
0.024\end{array}$ \\
\hline$=1$ if internet company & $\begin{array}{l}0.152^{* * *} \\
0.056\end{array}$ & $\begin{array}{l}0.225^{* * *} \\
0.064\end{array}$ & $\begin{array}{l}0.151^{* * *} \\
0.056\end{array}$ & $\begin{array}{l}0.151^{* * *} \\
0.057\end{array}$ & $\begin{array}{l}0.151^{* * * *} \\
0.057\end{array}$ & $\begin{array}{l}0.048 \\
0.070\end{array}$ \\
\hline “Bubble" & & & & & & \\
\hline$=1$ if in 1999 or 2000 & $\begin{array}{l}0.136^{* * *} \\
0.040\end{array}$ & $\begin{array}{l}0.139^{* * *} \\
0.039\end{array}$ & $\begin{array}{l}0.131^{* * * *} \\
0.040\end{array}$ & $\begin{array}{l}0.130^{* * *} \\
0.040\end{array}$ & $\begin{array}{l}0.131^{* * * *} \\
0.040\end{array}$ & $\begin{array}{l}0.093^{*} \\
0.049\end{array}$ \\
\hline Constant & $\begin{array}{l}0.111^{* *} \\
0.044\end{array}$ & $\begin{array}{l}0.103^{* *} \\
0.044\end{array}$ & $\begin{array}{l}0.109^{* *} \\
0.044\end{array}$ & $\begin{array}{l}0.087^{*} \\
0.045\end{array}$ & $\begin{array}{l}0.086^{*} \\
0.045\end{array}$ & $\begin{array}{l}0.210^{* * *} \\
0.053\end{array}$ \\
\hline $\begin{array}{l}R^{2} / \text { McFadden's } R^{2} \\
F \text {-test all coeff. }=0\end{array}$ & $\begin{array}{l}45.76 \% \\
35.68^{* * * *}\end{array}$ & $\begin{array}{l}46.09 \% \\
37.60^{* * * *}\end{array}$ & $\begin{array}{l}45.67 \% \\
36.83^{* * *}\end{array}$ & $\begin{array}{l}45.54 \% \\
39.63^{* * * *}\end{array}$ & $\begin{array}{l}45.55 \% \\
32.80^{* * * *}\end{array}$ & $\begin{array}{l}27.36 \% \\
35.73^{* * * *}\end{array}$ \\
\hline
\end{tabular}

